\title{
Approving the biocontrol method of potato wilt caused by Ralstonia solanacearum (Smith) using Enterobacter cloacae PS14 and Trichoderma asperellum T34
}

Bereika F. F. Mohamed ${ }^{1}$, Nashwa M. A. Sallam², Saad A. M. Alamri ${ }^{3,4}$, Kamal A. M. Abo-Elyousr ${ }^{2,5^{*}}$ (D), Yasser S. Mostafa ${ }^{3}$ and Mohamed Hashem ${ }^{3,6}$

\begin{abstract}
This study aimed to evaluate the efficiency of Enterobacter cloacae PS14 and Trichoderma asperellum T34 in the control of potato wilt, caused by Ralstonia solanacearum (Smith), under greenhouse and field conditions. In vitro, the endophyte E. cloacae PS14 caused the highest reduction of the pathogen growth among 7 screened bacteria. It produced an inhibition zone as $16.9 \mathrm{~mm}$ compared to a specific antibiotic $(20.0 \mathrm{~mm})$. E. cloacae PS14 was selected as an effective antagonistic bacterium to be compared to T. asperellum strain T34 for reduction of the disease as well as increasing the crop yield of potato plants. Both E. cloacae and T. asperellum reduced the disease severity up to $10.7-26.5 \%$, respectively, under greenhouse and up to $26.6-36.6 \%$, respectively, under field conditions. The results approved that both E. cloacae and T. asperellum increased the yield of the crop by 20.44$40.96 \%$, respectively. Their mode of action was indicated by suppression of the pathogen as well as induction of plant systemic resistance. The induction of systemic resistance was confirmed by increasing the total phenol and salicylic acid contents as well as increasing the activities of peroxidase, lipoxygenase, and polyphenol oxidase in potato plants than the healthy or only infected plants. Production of siderophore, indole-3-acetic acid (0.577$0.884 \mu \mathrm{M})$, hydrogen cyanide $(2.34-3.61 \mu \mathrm{g} / \mathrm{ml})$, and salicylic acid $(0.436-1.488 \mu \mathrm{g} / \mathrm{ml})$ was confirmed by E. cloacae PS14 and T. asperellum T34, respectively, in vitro. The study recommends the new strain E. cloacae PS14, as new endophytic effective bacteria, in the control of $R$. solanacearum causing the potato wilt disease.
\end{abstract}

Keyword: Potato wilt, Endophyte, Biological control, Enterobacter cloacae, Trichoderma asperellum, Systemic resistance

\section{Background}

Bacterial wilt disease caused by Ralstonia solanacearum (Smith) is one of the serious plant diseases worldwide (Peeters et al. 2013). In Egypt, as well as in many countries, it has become a severe problem for the production of potato plant (Abo-Elyousr and Bagy 2018).

\footnotetext{
* Correspondence: kaaboelyousr@agr.au.edu.eg

2Plant Pathology Department, Faculty of Agriculture, Assiut University, Assiut, Egypt

${ }^{5}$ Faculty of Meteorology, Env., and Arid Land Agriculture, Department of Arid Land Agriculture, King Abdulaziz University, Jeddah, Saudi Arabia Full list of author information is available at the end of the article
}

Traditional control methods such as short rotation, resistant cultivars, and soil fumigation have been suggested. However, such methods are not always enough effective since $R$. solanacearum can remain with the infested plant debris in the soil for a long time. Recently, the research focuses on some alternative methods to control the disease that are characterized by being environmentally safe, long lasting and effectiveness (AboElyousr and Bagy 2018).

Biological control, using beneficial microorganisms, could therefore, be a choice for managing the disease 
(Abd-El-Khair 2020). Many beneficial microbes such as P. fluorescens spp., Acinetobacter spp., Bacillus spp., Bacteriophages, Enterobacter spp., Pseudomonas putida, Paenibacillus macerans, Streptomyces, and Trichoderma spp. have been documented as effective biocontrol agents against $R$. solanacearum (Ling et al. 2010). Trichoderma spp. have been focused on their antagonistic and mycoparasitic ability to reduce the disease incidence caused by phytopathogens (El-Sharkawya et al. 2018). They play an important role in controlling of soil-borne pathogens, stimulating the plant growth, and enhancing the crop productivity (Sallam et al. 2019). Some of Trichoderma spp. are manufactured and marketed worldwide as commercial biological products, used as soil fertilizers, plant biostimulant, and biofungicide (Woo et al. 2014). Many reports indicated that Trichoderma could induce resistance in plants not only by producing proteins, but also by producing secondary metabolites in the soil amended with decomposed organic fertilizer, which has decreased the $R$. solanacearum population (Konappa et al. 2018).

The endophytic bacteria are those that could internally colonize plants without induction of any apparent negative effects on the plant morphology and physiology (Gaiero et al. 2013). They are increasingly characterized by their possible use in the phytoremediation, promotion of plant growth, reduction of abiotic stress, and antagonism against many pathogens (Mercado-Blanco and Lugtenberg 2014). Interestingly, wilt disease of some crops such as tomato, caused by $R$. solanacearum, has been controlled by endophytic bacteria: Pantoea ananatis, Pseudomonas oleovorans, and Enterobacter cloacae (Upreti and Thomas 2015). It was reported that common genera such as Sphingobacterium, Comamonas, Arthrobacter, Curtobacterium, Paenibacillus, Xanthomonas, Serratia, Pantoea, Variovorax Stenotrophomonas, and Enterobacter were frequently isolated from the rhizospheric soil of potato, and many of them were used as potential biocontrol agents (Chamedjeu et al. 2019). For example, Götz et al. (2006) used Enterobacter cowanii as biocontrol agents against bacterial wilt of tomato. E. cloacae was used successfully for controlling many plant diseases such as Fusarium wilt of spinach (Tsuda et al. 2001), bacterial blight of rice (Yang et al. 2000), dry rot of potato (Al-Mughrabi 2010), and damping-off of tomato (Yuliar et al. 2019).

To the best of the authors' knowledge, this is the first time to use E. cloacae and T. asperellum, as a field trial, against $R$. solanacearum, the causal pathogen of potato wilt. The aim of this study was to investigate the biocontrol efficiency of $E$. cloacae PS14 and Trichoderma asperellum T34 to manage the wilt disease of potato under field conditions as well as exploring the biochemical responses in relation to defense enzymes that induce the resistance of plants against pathogen.

\section{Materials and methods}

\section{Bacterial pathogen}

$R$. solanacearum isolate PHYRS3, the causal agent of potato wilt disease, was isolated in a previous work by Bereika (2008). In brief, samples of diseased potato plants showing wilt symptoms were washed 2-3 times by tap water, followed by sterile water and sterilized with $2 \%$ sodium hypochlorite solution; the disinfected plant samples were homogenized with $5 \mathrm{ml}$ of sterile $0.05-\mathrm{M}$ potassium phosphate buffer in a sterilized mortar and pestle. A loop of the resulted suspension was streaked onto 2,3,5-triphenyl tetrazolium chloride (TZC) agar medium in $9.0-\mathrm{cm}$ Petri plates and then incubated at $27^{\circ} \mathrm{C}$ for $48 \mathrm{~h}$ and examined daily for bacterial growth. The single colony technique was used to obtain pure cultures of the isolated bacteria by growing on the same media used and kept at $4{ }^{\circ} \mathrm{C}$ for further studies.

\section{Microorganisms \\ Trichoderma asperellum strain T34}

T. asperellum strain T34 was obtained from Biocontrol Technologies S.L. Company Spain and reactivated and maintained on potato dextrose agar (PDA).

\section{Endophytic bacteria}

The endophytic bacteria were isolated from healthy potato plants, collected from Assiut Governorate, Egypt, during winter 2016. Segments of potato stems $(2 \mathrm{~cm})$ were surface-sterilized, using $2 \%$ sodium hypochlorite for $3 \mathrm{~min}$, then with $70 \%$ ethanol for $30 \mathrm{~s}$. The segments were rinsed by sterile distilled water 3 times and homogenized in $10 \mathrm{ml}$ acetate buffer (pH 5.2). The homogenized plant tissue was taken by a loop and streaked on the surface of Petri dishes $(9 \mathrm{~cm})$ containing nutrient agar medium (NA). The plates were incubated at $28^{\circ} \mathrm{C}$ for $48 \mathrm{~h}$. Seven bacterial strains were recovered and their pure cultures were kept on NA slants and preserved at $4{ }^{\circ} \mathrm{C}$ for further use.

\section{Evaluation of antagonistic potentially of the endophytic bacteria against $R$. solanacearum}

The antagonistic and pathogenic bacteria were grown individually in 250-ml Erlenmeyer conical flasks containing $100 \mathrm{ml}$ of nutrient sucrose broth and incubated at $28^{\circ} \mathrm{C}$ for $48 \mathrm{~h}$, and $150 \mathrm{rpm}$. After incubation, the bacterial growth was centrifuged at $10000 \times g$ in sterile microfuge tubes. The supernatants were excluded, and the bacterial cells were collected. Using spectrophotometer (at $600-\mathrm{nm}$ ), the bacterial cell density was adjusted to $10^{8} \mathrm{cell} / \mathrm{ml}$. The antagonistic activities of seven isolates of the endophytic bacteria were evaluated using the dual culture against $R$. solanacearum PHYRS3 based on the method described by Abo-Elyousr et al. (2012) with modification. Briefly, a suspension of $R$. solanacearum 
PHYRS3 $\left(100 \mu \mathrm{l}\right.$ at $\left.10^{8} \mathrm{cell} / \mathrm{ml}\right)$ was spread over agar surface. After drying, $100 \mu \mathrm{l}$ of each antagonistic isolate $\left(10^{8} \mathrm{cell} / \mathrm{ml}\right)$ were individually pipetted into $5-\mathrm{mm}$ punches in the same agar inoculated with the pathogen. The antibiotic streptomycin $(1.0 \mathrm{mg} / \mathrm{ml})$ was used as positive control. After 2 days from incubation at $28^{\circ} \mathrm{C}$, the antibacterial effect of the strains was monitored by measuring the diameter of the inhibition zone $(\mathrm{mm})$. The experiment was repeated twice with four replicates for each treatment.

\section{Identification of the potent antagonistic bacterial strain}

Based on the above test, the potent antagonistic bacterial strain was selected for identification via $16 \mathrm{~s}$ rRNA sequencing according the following protocol.

\section{DNA isolation}

The genomic DNA was extracted from the endophytic bacterial strain using the genomic DNA Prep kit (SolGent, Daejeon, Korea) following to the manufacturer's instructions. The extracted DNA was used as a template for PCR to amplify the 16S rRNA gene. Universal bacterial primers 27F (5'-AGA GTT TGA TCC TGG CTC AG-3') and 1492R (5'-GGT TAC CTT GTT ACG ACT T-3') were used to amplify the nearly complete $16 \mathrm{~S}$ rRNA gene (Abd-Alla et al. 2012).

\section{PCR amplification}

The PCR amplification was performed in a $25-\mu$ reaction volume containing $0.4 \mu \mathrm{M}$ of each primer, $0.75 \mathrm{U}$ of EF-Taq DNA polymerase (SolGent, Daejeon, Korea), 0.2 $\mathrm{mM}$ of each d NTP, 10-50 ng of the template DNA, and $1 \times$ EF-Taq reaction buffer. The thermo cycling conditions included an initial denaturation step at $95^{\circ} \mathrm{C}$ for $15 \mathrm{~min}$, followed by 30 cycles at $95^{\circ} \mathrm{C}$ for $20 \mathrm{~s}, 50^{\circ} \mathrm{C}$ for $40 \mathrm{~s}$, and $72^{\circ} \mathrm{C}$ for $1.5 \mathrm{~min}$ with a final extension step at $72{ }^{\circ} \mathrm{C}$ for $5 \mathrm{~min}$. The PCR product was separated by $1.5 \%$ agarose gel electrophoresis containing ethidium bromide with buffer of $0.5 \times$ Tris-acetate-EDTA (TAE) and visualized using a UV illuminator (Abd-Alla et al. 2012).

\section{DNA sequencing}

The PCR product was purified according to the manufacturer's instructions using a SolGent PCR purification kit (SolGent, Daejeon, Korea) (Sanger et al. 1977). The partial 16S rRNA gene sequence was compared to full sequences available in the GenBank database, using a BLAST search (NCBI) for identification of the bacterial strain. Sequences obtained with those retrieved from GenBank database and the sequenced data were deposited in the GenBank under a specific accession number.
Effect of E. cloacae PS14 and T. asperellum T34 on diseases severity under greenhouse conditions

The greenhouse trials were conducted at the Experimental Greenhouse of Department Plant Pathology, Assiut, Egypt, during the 2017 growing season. Healthy potato tubers (Solanum tuberosum L.) cv. Berema were surfacesterilized by soaking in $2 \%$ sodium hypochlorite for 3 min, washed thoroughly with sterilized distilled water and planted directly in sterilized $25-\mathrm{cm}$ diameter pots. Pots and soil were sterilized by $5 \%$ formalin and left for 15 days before planting. Pots filled with $5-\mathrm{kg}$ sterilized sandy-clay soil $(3: 1 \mathrm{w} / \mathrm{w})$ were kept in the greenhouse under natural temperatures and photoperiods during the growing season. Plants were fertilized every 15 days with ( $20 \mathrm{~g} /$ pots) of $46 \%$ urea and irrigated with water when necessary. Forty-five days after planting, potato cultivar was inoculated with $R$. solanacearum PHYRS3 (the pathogen) suspended in water at $10^{8} \mathrm{cell} / \mathrm{ml}$, by using an alcohol knife which was inserted $4-5 \mathrm{~cm}$ into the soil to cut the roots along two sides and $20 \mathrm{ml}$ of $R$. solanacearum PHYRS3 suspension was added to each plant around the basis of each plant (Bereika 2008). Infected control plants were inoculated with the pathogen only and treated with $20 \mathrm{ml}$ sterile distilled water, while healthy control did not receive any treatment (without infection and without treatment). After inoculation, the potato cultivar was kept in a moist chamber at $25^{\circ} \mathrm{C}$ for 2 days before being transferred to the greenhouse at 25$30^{\circ} \mathrm{C}$. Two days after inoculation, $20 \mathrm{ml}$ from each agent suspension (E. cloacae PS14 or T. asperellum T34) was added surrounding the bases of plants. Four replicates were used for each treatment. After 6 weeks, the development of bacterial wilt symptoms was observed. The disease severity was monitored and the percentage of disease severity (DS\%) was estimated using the formula suggested by Kempe and Sequeira (1983).

\section{Disease assessment}

Disease severity was recorded, using the scale of Kempe and Sequeira (1983) as follows:

$0=$ no symptoms, $1=1-25 \%$ of leaves wilted, $2=26-$ $50 \%$ of leaves wilted, $3=51-75 \%$ of leaves wilted, $4=$ more than $75 \%$ and less than $100 \%$ of leaves wilted, and $5=$ all leaves wilted and died. Disease severity percentage was calculated by the following equation:

$\mathrm{DS} \%=[\Sigma \mathrm{d} / d(\max \times n)] \times 100$

where " $d$ " is the disease rating on each plant, " $d$ max" is the maximum disease rating possible, and " $n$ " is the total number of plants examined in each replicate.

\section{Application of E. cloacae PS14 and T. asperellum T34 under field conditions}

The experiments were carried out at the farm of Faculty of Agriculture, Assiut University, Egypt. Four replicates 
were used for each treatment and the treatments were distributed in a completely randomized block design. The experimental plot area was $25-\mathrm{m}^{2}$ containing 5 rows, each row was $4.5-\mathrm{m}$ in length and the distance between each row was $0.5 \mathrm{~m}$. Potato seed tubers $(\mathrm{cv}$. Berema) were sown on the middle of the ridge at 0.4-m apart. After one month from planting, each treatment was added singly to the plant's soil by drenching around the plants at 20-ml from each microorganism before 48 $\mathrm{h}$ of inoculation with $R$. solanacearum PHYRS3 $\left(10^{8}\right.$ cell $/ \mathrm{ml}$ ) as described in greenhouse experiment. The control plants were treated by $20-\mathrm{ml}$ distilled water after cutting (Winstead and Kelman 1952) and the disease severity was recorded after 6 weeks after inoculation according to Kurabachew and Wydra (2013). At harvest time (110 days after planting), potato plants of 6 plants from each replicate were pulled for measuring a total tuber yield $(\mathrm{kg})$ per replicate and the yield was expressed as ton/hectare.

\section{Biochemical analyses}

The effects of E. cloacae PS14 and T. asperellum T34 on biochemical changes of the inoculated potato plants by R. solanacearum PHYRS3 were investigated. Leaves samples were taken at zero time and at $2,4,6$, and 8 days after inoculation for determination of total phenoland salicylic acid contents and enzyme activities.

\section{Determination of total phenol and salicylic acid contents}

One gram of potato plant's leaves was crushed in liquid nitrogen and homogenized in $10-\mathrm{ml}$ of $80 \%$ methanol. The homogenate was centrifuged at $10,000 \mathrm{~g}$ for $30 \mathrm{~min}$ at $4{ }^{\circ} \mathrm{C}$. The pellets were wasted after adding ascorbic acid $(0.1 \mathrm{~g} / 5 \mathrm{ml})$. The homogeneous product was evaporated at $65^{\circ} \mathrm{C}$ in a rotary evaporator and the process was repeated 3 times each for $5 \mathrm{~min}$. The residues were dissolved in $5 \mathrm{ml}$ of $80 \%$ methanol. For each treatment, 4 replicates were used (Rapp and Ziegler 1973). The method of Abo-Elyousr et al. (2008) was used to determine phenol content as milligrams gallic acid/gram plant material. Salicylic acid content was estimated, using a modified method by Dat et al. (1998) as micrograms salicylic acid/gram plant material.

\section{Enzymes activity}

For determination of activities of peroxidase (PO), polyphenol oxidase (PPO), and lipoxygenase (LO), $1 \mathrm{~g}$ of fresh potato plants' leaves was treated with liquid nitrogen and homogenized with $10-\mathrm{ml}$ of $0.1 \mathrm{M}$ Na-acetate buffer ( $\mathrm{pH}$ 5.2). The mixture was centrifuged at 10,000 g for $30 \mathrm{~min}$ at $4{ }^{\circ} \mathrm{C}$ and the enzyme activity was determined in the supernatants. Four replicates were used for each treatment. Total protein was estimated based on the method described by Bradford (1976) using Bradford reagent spectrophotometrically at 595-nm using Bovine serum albumin as standard.

Peroxidase (PO) activity The enzyme activity was determined spectrophotometrically by the method of Putter (1974), using guaiacol as a substrate. The reaction mixture was composed of $0.2 \mathrm{ml}$ supernatant, $1 \mathrm{ml}$ of $0.1 \mathrm{M} \mathrm{Na}$-acetate-buffer ( $\mathrm{pH} 5.2$ ), $0.2 \mathrm{ml}$ of $1 \% \mathrm{H}_{2} \mathrm{O}_{2}$ and $0.2 \mathrm{ml}$ of $1 \%$ guaiacol. The mixture was incubated for 5 min at $25^{\circ} \mathrm{C}$ and then measured at $436 \mathrm{~nm}$. The blank was used with extraction buffer. The PO activity was calculated according to the change in absorbance and expressed as enzyme per $1 \mathrm{mg}$ protein.

Polyphenol oxidase (PPO) activity The enzymatic activity was determined, using the method described by Batra and Kuhn (1975). The reaction mixture was $0.5 \mathrm{ml}$ of the supernatant, $2 \mathrm{ml}$ of $50 \mathrm{mM}$ Sorensen phosphate buffer (g/l: $\mathrm{KH}_{2} \mathrm{PO}_{4}, 6.8 ; \mathrm{Na}_{2} \mathrm{HPO}_{4} \cdot 2 \mathrm{H}_{2} \mathrm{O}$, 8.99; EDTA, 0.372 and distilled water up to $1000 \mathrm{ml}, \mathrm{pH}$ was adjusted to 6.5 ) and $0.5 \mathrm{ml}$ of the substrate Bren catechol (Sigma Aldrich). The mixture was incubated for $2 \mathrm{~h}$ in water bath at $37^{\circ} \mathrm{C}$ and measured at $410 \mathrm{~nm}$. Activity of PPO $=\mathrm{OD}$ at $410 \mathrm{~nm} / \mathrm{mg}$ protein.

\section{Lipoxygenase (LOX) activity}

The enzymatic activity was evaluated according to the protocol of Axelred et al. (1981), the increasing in lipoxygenase activity was measured according to the increase in absorbance at 234-nm resulting from the conjugated double-bond system in the hydroperoxide produced from the substrate, linoleic acid $(10-\mathrm{mM}$ sodium linoleate; $\mathrm{pH} 9$ ). The mixture contained $10 \mu \mathrm{l}$ of mixture, $20 \mu \mathrm{l}$ of the substrate, and $1 \mathrm{ml}$ of $50 \mathrm{mM}$ sodium phosphate buffer ( $\mathrm{pH}$ 6). Absorbance readings were made spectrophotometrically for $3 \mathrm{~min}$ at room temperature. A mixture containing buffer and substrate was used as a blank. The activity was measured from the extinction coefficient of $25 \mathrm{mM}^{-1} \mathrm{~cm}^{-1}$.

\section{Possible mode of action exerted by E. cloacae PS14 and $T$. asperellum T34 \\ Salicylic acid production}

Salicylic acid (SA) produced by E. cloacae PS14 and T. asperellum T34 were determined, following the method described by Meyer and Abdallah (1978). The microorganisms were grown in the standard succinate medium at $28^{\circ} \mathrm{C}$ for 48 -h components from $\mathrm{K}_{2} \mathrm{HPO}_{4}(11.5 \mathrm{~g} / \mathrm{l})$, $\left(\mathrm{NH}_{4}\right)_{2} \mathrm{SO}_{4}(28.7 \mathrm{~g} / \mathrm{l})$, and distilled water up to $1000 \mathrm{ml}$. The $\mathrm{pH}$ was adjusted to 7.0 with $20 \% \mathrm{NaOH}$ prior to autoclaving. Cells were collected by centrifugation at $8000 \times g$ for $5 \mathrm{~min}$ and re-suspended in $1 \mathrm{ml}$ of $0.1 \mathrm{M}$ phosphate buffer. A 4-ml of cell-free culture supernatant was acidified with $1-\mathrm{N} \mathrm{HCl}$ to $\mathrm{pH} 2.0$ and $\mathrm{SA}$ was 
extracted in $\mathrm{CHCl}_{3}$. Four milliliters of water and $5 \mu \mathrm{l}$ of 2-M $\mathrm{FeCl}_{2}$ were added to the pooled $\mathrm{CHCl}_{3}$ phases. The absorbance of the purple iron-SA complex, developed in the aqueous phase, was read at $527 \mathrm{~nm}$. A standard curve was prepared with SA dissolved in succinate medium and quantity of SA produced was calculated.

\section{Indole acetic acid production}

E. cloacae PS14 and T. asperellum T34 were inoculated by TSB with tryptophan as a precursor $(100 \mu \mathrm{g} / \mathrm{ml})$ on a shaker for $30 \mathrm{~min}$. The culture's supernatants were collected after centrifugation for $10 \mathrm{~min}$ at $2000 \mathrm{rpm}$ and 1 $\mathrm{ml}$ of cell-free culture filtrate was mixed with $2 \mathrm{ml}$ of Salkowski reagent $(1 \mathrm{ml}$ of $0.5 \mathrm{M} \mathrm{FeCl}$ in $50 \mathrm{ml}$ of $35 \%$ perchloric acid) and incubated at $28^{\circ} \mathrm{C}$ for $30 \mathrm{~min}$. Quantification was done calorimetrically at $530 \mathrm{~nm}$ comparing to indole acetic acid production (IAA) standard curve (Nandhini et al. 2012).

\section{Quantitative detection of hydrogen cyanide and siderophore}

The antagonistic microorganisms were grown in trypticase soy broth (TSB, Hi media, India). Filter paper was cut into uniform strips of $10-\mathrm{cm}$-long and 0.5 -cm-wide saturated with alkaline picrate solution and placed inside the test tubes in hanging positions. After incubation for $48 \mathrm{~h}$ at $28^{\circ} \mathrm{C}$, the sodium picrate in the filter paper was reduced to a reddish compound in proportion to the quantity of hydrocyanic acid evolved. The color was eluted by placing the filter paper in a clean glass test tube containing $10 \mathrm{ml}$ of distilled water and absorbance was measured at $625 \mathrm{~nm}$ (Sadasivam and Manickam 1992).

The quantitative estimation of siderophore produced by bioagents was done by CAS-shuttle assay (Schwyn and Neilands 1987). The strains were grown in a succinate medium and incubated at $28^{\circ} \mathrm{C}$ for 24 to $30 \mathrm{~h}$ and shaking at $120 \mathrm{rpm}$. After incubation, the fermented broth was taken and centrifuged at $10,000 \times g$ for $10 \mathrm{~min}$ at $4{ }^{\circ} \mathrm{C}$ and the cell-free supernatant was mixed by $0.5 \mathrm{ml}$ CAS solution. The color obtained was determined at $630 \mathrm{~nm}$ after $20 \mathrm{~min}$ from incubation with reference containing $0.5 \mathrm{ml}$ CAS solution with $0.5 \mathrm{ml}$ uninoculated succinate medium. The percentage of siderophore units was determined as the proportion of CAS color shifted using the formula\% Siderophore units $=\left(A_{r}\right.$ - $\left.A_{s} / A_{r}\right) \times 100$, where $A_{r}=$ Absorbance of reference at $630 \mathrm{~nm}$ (CAS reagent) and $A_{S}=$ Absorbance of sample at $63 \mathrm{~nm}$

\section{Statistical analysis}

Data were initially examined for their normal distribution of errors using Shapiro-Wilk's $W$ test and for homogeneity of variances using Levene's test. All statistical analyses were performed with SPSS 22.0 software.
The data were analyzed for significance of variation using one-way analysis of variance (ANOVA) for antagonistic capability and for the rest of experiments twoway analysis were used. The least significant difference (LSD) test was used at $P<0.05$ to identify the significant differences among the means of the treatments according to Gomez and Gomez (1984).

\section{Results and discussion}

\section{Antagonistic activity and identification of the endophyte}

\section{E. cloacae PS14}

The antagonistic activity of 7 bacterial isolates against $R$. solanacearum PHYRS3 was evaluated, using dual culture method (Table 1). The results indicated that the highest inhibitory effect against the PHYRS3 was attributed to the bacterial strain no. 7, which caused production of inhibition zone as $16.9 \mathrm{~mm}$ compared with $20.0 \mathrm{~mm}$ because of specific antibiotic streptomycin. The potent antagonistic bacterium was identified by $16 \mathrm{~S}$ rRNA gene and their sequences were compared to data available in the GenBank using BLAST search. The results indicated that the bacterial strain belongs to the genus Enterobacter and it could be identified as E. cloacae (Table 2) with a similar, percentage as $86.22 \%$. It was given a specific strain number as E. cloacae PS14 and it was allocated in the GenBank under accession number Mn385618. The findings could be supported by those of Upreti and Thomas (2015) who isolated E. cloacae, Pantoea ananatis, and Pseudomonas oleovorans as endophytic bacteria from different tomato cultivars. However, a relatively low similarity percentage of the strain identity with those allocated in the GenBank could support our hypothesis that it is a new strain of E. cloacae that has specific characteristics such as its antagonistic potency and biological control efficiency against the target pathogen. The use of plant-associated microorganisms in biological control of plant diseases was mentioned as an efficient and ecofriendly method (Xue et al. 2009). The suppressive effect

Table 1 Effect of seven endophytic bacterial isolates on growth of Ralstonia solanacearum in vitro

\begin{tabular}{ll}
\hline Treatments & Inhibition zone $(\mathrm{mm})$ \\
\hline Isolate no. 1 & $3.0 \pm 1.0 \mathrm{~d}$ \\
Isolate no. 2 & $1.0 \pm 1.0 \mathrm{f}$ \\
Isolate no. 3 & $5.0 \pm 0.1 \mathrm{C}$ \\
Isolate no. 4 & $2.0 \pm 1.0 \mathrm{e}$ \\
Isolate no. 5 & $3.0 \pm 1.0 \mathrm{~d}$ \\
Isolate no. 6 & $2.0 \pm 1.0 \mathrm{e}$ \\
Isolate no. 7 & $16.9 \pm 1.0 \mathrm{~b}$ \\
Streptomycin $(1.0 \mathrm{mg} / \mathrm{ml})$ & $20.0 \pm 1.0 \mathrm{a}$ \\
Sterilized water & $0.0 \pm 0.0$
\end{tabular}

Values followed by the same letter are not significantly different as determined by the LSD test $(P \leq 0.05)$ 
Table 2 Identification of endophytic bacterium Enterobacter cloacae PS14 by 16 rRNA gene sequences based on the matching similarity in the GenBank

\begin{tabular}{|c|c|c|c|c|c|c|c|c|}
\hline Query length (bp) & Molecule type & Identities (\%) & Query coverage & Max score & Total score & $E$ value & Taxonomic name & GenBank accession no. \\
\hline 1971 & Nucleic acid & $86.22(870 / 1009)$ & $94 \%$ & 1055 & 12877 & 0.0 & Enterobacter cloacae & Mn385618 \\
\hline
\end{tabular}

of the antagonistic bacterium against the pathogen could be mainly due to its antibiosis activity, where it has the ability to synthesize certain molecules to inhibit the pathogen development that was indicated by an inhibition zone around their growth (Chamedjeu et al. 2019).

\section{Efficiency of E. cloacae PS14 and T. asperellum T34 in controlling the wilt of potato under greenhouse and field conditions}

The results illustrated in Figs. 1 and 2 showed that the antagonists, E. cloacae PS14, and T. asperellum T34 significantly decreased the disease severity of wilt disease than the control (infected plants with the pathogen only) under greenhouse conditions. The disease severity was reduced by 10.73 and $26.50 \%$ due to the 2 respective bioagents, compared to $93.25 \%$ due to the pathogenic bacterium. Under field conditions, the bioagents successfully protected the potato plants against the destructive effect of the pathogen (Table 3). The disease severity was reduced by $39.00-49.06 \%$ from the infected control as the result of application of microorganisms, during the 2 seasons of the experiment. The used of both agents caused increasing the productivity of the crop by 20.44$40.96 \%$ relative to the control during the 2 seasons. Obtained results are somewhat in agreement with those of Upreti and Thomas (2015), who used P. oleovorans, Pantoea ananatis, and E. cloacae to manage the disease caused by $R$. solanacearum on tomato plants. These authors mentioned that the presence of endophytic bacteria, that have antagonistic potentiality against pathogenic organisms, could reveal a possible role of endophytes associated with the root in natural defense against the pathogens. Also, Podolich et al. (2015) reported that endophytic bacteria may play an important role in crop protection by stimulating their active form in response to environmental stress or pathogen attack as well as improving the growth and plant health.

\section{Effect of E. cloacae PS14 and T. asperellum T34 on production of biochemical precursors causing resistance's induction in potato plant \\ Phenol compounds}

Salicylic acid Results showed a significant increase in salicylic acid content in the inoculated potato plants with T. asperellum T34 and E. cloacae PS14 than either only infected control or healthy plants (Fig. 3). The SA accumulation increased, 2 days after inoculation of plants, with the bioagents until the 8th day and SA content in plants, treated with $T$. asperellum, was higher than those treated with E. cloacae. The increase in SA content in the treated plants confirms the hypothesis that both rhizobacteria (PGPR) and Trichoderma spp. could stimulate the plant resistance, in addition to their suppressive effect on the phytopathogens. It was confirmed that these microorganisms were able to stimulate

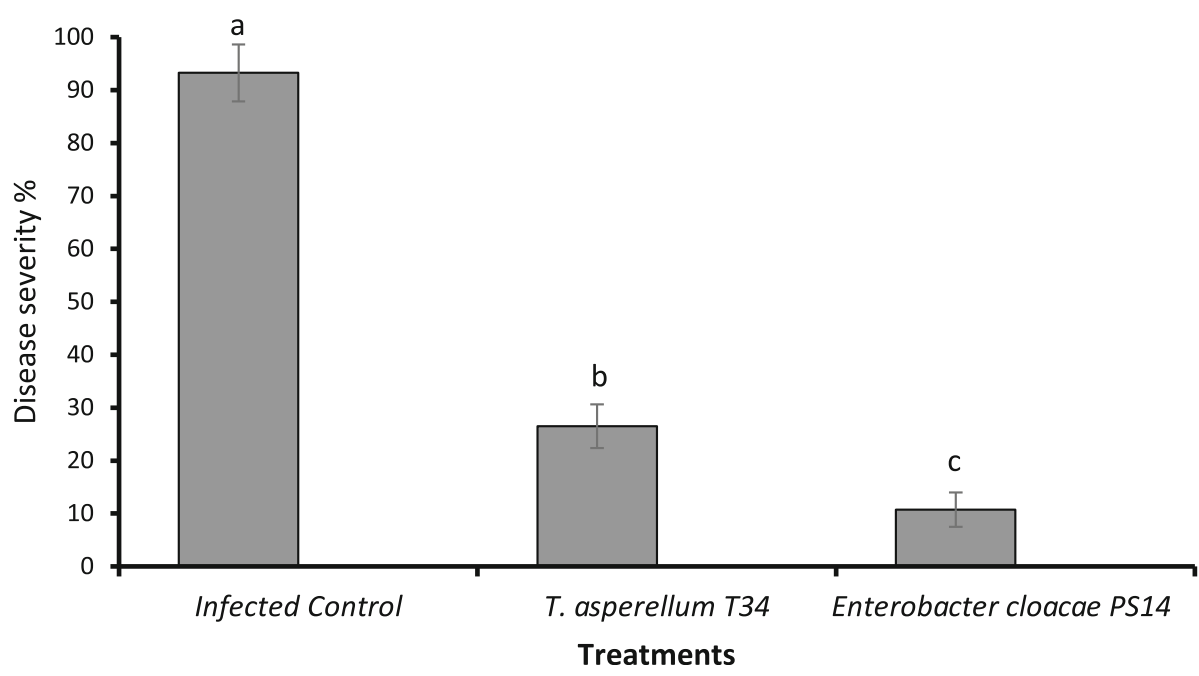

Fig. 1 Effect of Enterobacter cloacae PS14 and Trichoderma asperellum T34 on disease severity\% of wilt on potato plants under greenhouse conditions 


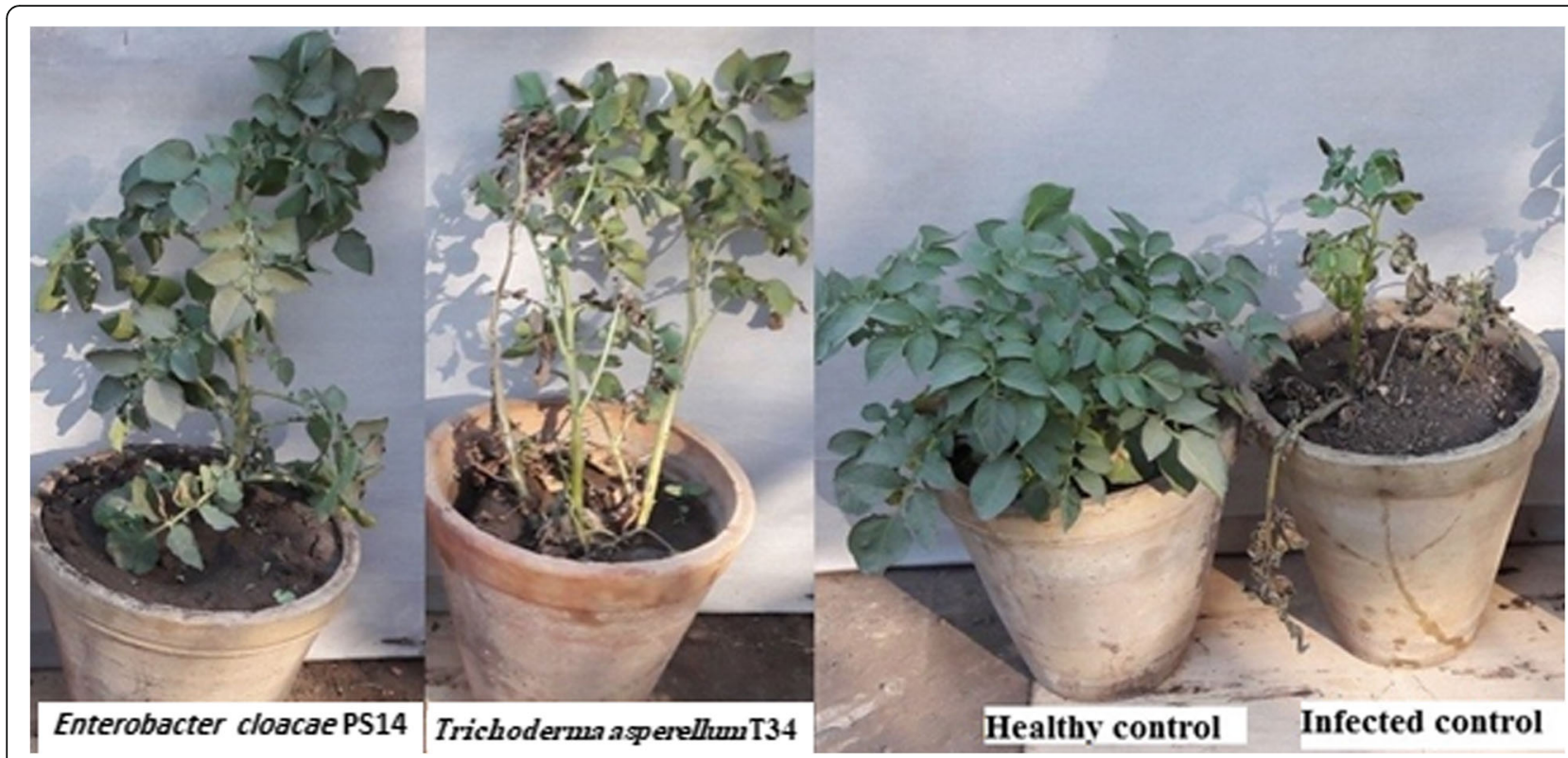

Fig. 2 Symptoms of wilt disease on potato plants treated with the Enterobacter cloacae PS14 and Trichoderma asperellum T34 compared to heathy and infected plants under greenhouse conditions

plant growth by mediating the plant hormones ethylene (ET) and induction of the resistance in plants through production of salicylic acid (SA) and jasmonic acid (JA) (Hermosa et al. 2012). Hassan and Abo-Elyousr (2013) suggested that SA accumulation was essential for expression of multiple modes of plant disease resistance. Because SA is a plant defense phenolic compound against pathogens, it should be detected in both infected and distal leaves in response to pathogen attacks. Obtained results confirm that enhanced SA contents are, thus, a prerequisite for expression systemic acquired resistance against $R$. solanacearum in potato plants.

Total phenol content The total phenol contents in the inoculated potato plants with the pathogen and treated with T. asperellum T34 and E. cloacae PS14 were significantly higher than that in only infected plants (control) or healthy plants (Fig. 4). The total phenol content in plants, treated with the 2 agents began to increase after the first 2 days from inoculation until the 6 th day and then the concentrations began to decrease, however, the increase was not significantly different. These results agree with those of Vinayarani and Prakash (2018) who reported that the accumulation of phenolics was observed in turmeric rhizomes treated with $T$. asperellum after the 2nd from inoculation with the Pythium aphanidermatum and the maximum accumulation was observed on the 5th day after inoculation (Vinayarani and Prakash 2018). Khan and Bano (2019) mentioned that treatment of wheat plants with PGPR bacteria increased

Table 3 Effect of the Enterobacter cloacae PS14 and Trichoderma asperellum T34 on wilt diseases severity and tuber yield on potato plants under field conditions during in two trail seasons.

\begin{tabular}{|c|c|c|c|c|c|c|c|c|}
\hline \multirow[t]{2}{*}{ Treatment } & \multicolumn{4}{|l|}{ Season 2017} & \multicolumn{4}{|l|}{ Season 2018} \\
\hline & $\begin{array}{l}\text { Disease } \\
\text { severity (\%) }\end{array}$ & $\begin{array}{l}\text { Reduction of disease } \\
\text { severity (\%) }\end{array}$ & $\begin{array}{l}\text { Yield (ton/ } \\
\text { hectare) }\end{array}$ & $\begin{array}{l}\text { Increasing of } \\
\text { yield (\%) }\end{array}$ & $\begin{array}{l}\text { Disease } \\
\text { severity (\%) }\end{array}$ & $\begin{array}{l}\text { Reduction of } \\
\text { disease severity }\end{array}$ & $\begin{array}{l}\text { Yield (ton/ } \\
\text { hectare) }\end{array}$ & $\begin{array}{l}\text { Increasing of } \\
\text { yield (\%) }\end{array}$ \\
\hline $\begin{array}{l}\text { Trichoderma } \\
\text { asperellum T34 }\end{array}$ & $\begin{array}{l}36.60 \pm 5.77 \\
b\end{array}$ & 39.00 & $\begin{array}{l}30.45 \pm \\
3.51 \mathrm{ab}\end{array}$ & 33.70 & $\begin{array}{l}33.7 \pm 0.16 \\
b\end{array}$ & 42.20 & $\begin{array}{l}31.42 \pm \\
2.03 \mathrm{ab}\end{array}$ & 40.96 \\
\hline $\begin{array}{l}\text { Enterobacter } \\
\text { cloacae PS14 }\end{array}$ & $\begin{array}{l}26.70 \pm 2.89 \\
c\end{array}$ & 48.83 & $\begin{array}{l}27.46 \pm \\
5.13 \mathrm{bc}\end{array}$ & 20.44 & $\begin{array}{l}29.70 \pm 1.30 \\
c\end{array}$ & 49.06 & $\begin{array}{l}29.03 \pm \\
0.91 b\end{array}$ & 30.24 \\
\hline Infected control & $\begin{array}{l}60.00 \pm 10.0 \\
a\end{array}$ & - & $\begin{array}{l}22.80 \pm \\
4.16 \mathrm{~cd}\end{array}$ & - & $\begin{array}{l}58.30 \pm 0.37 \\
a\end{array}$ & - & $\begin{array}{l}22.29 \pm \\
0.41 c\end{array}$ & - \\
\hline Healthy control & $0.0 \pm 0.0$ & - & $\begin{array}{l}32.60 \pm \\
1.46 \mathrm{a}\end{array}$ & 42.98 & $0.0 \pm 0.0 c$ & - & $\begin{array}{l}32.80 \pm \\
2.26 \mathrm{a}\end{array}$ & 47.25 \\
\hline
\end{tabular}

Values in the same column followed by the same letter(s) are not significantly different as determined by the LSD test $(P \leq 0.05)$ 


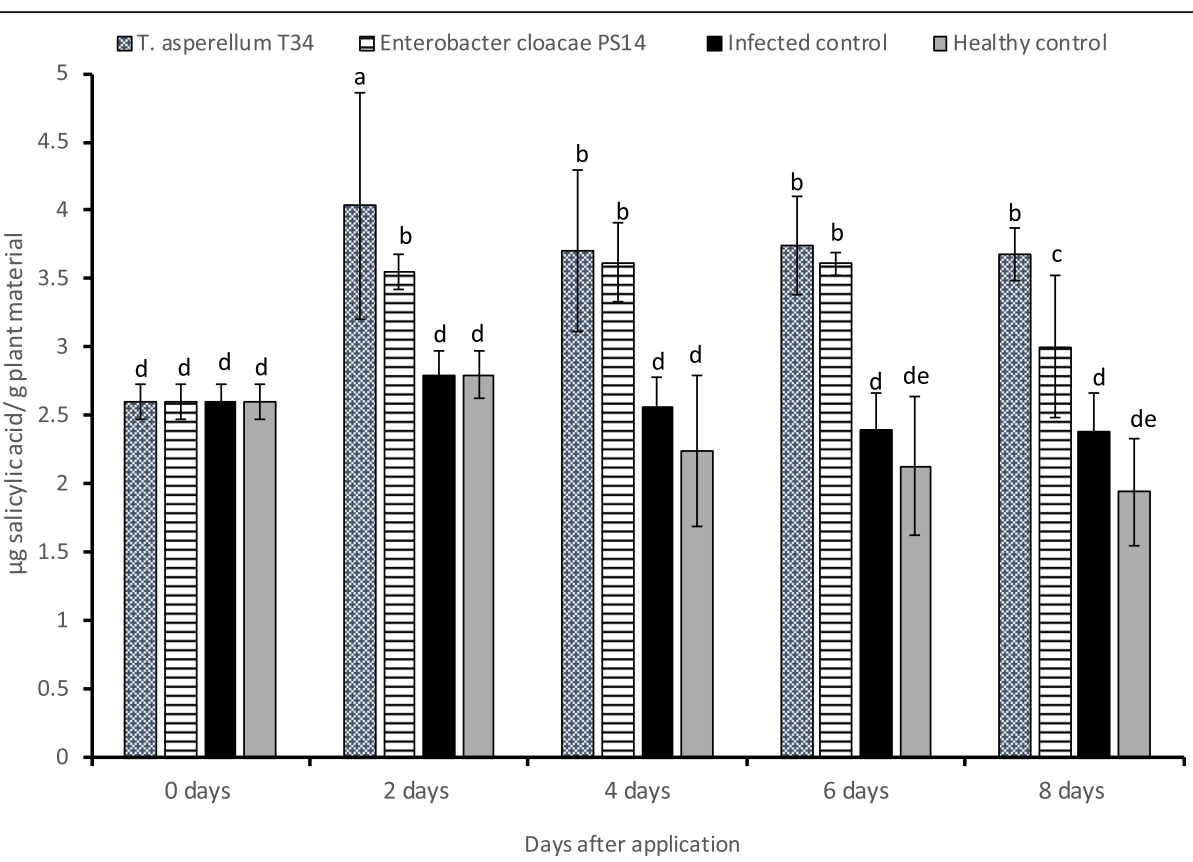

Fig. 3 Effect of application of the Enterobacter cloacae PS14 and Trichoderma asperellum T34 on salicylic acid contents (SA) in potato plants after inoculation with Ralstonia solanacearum PHYRS3. Columns having the same letter are not significantly different at $P<0.05$

the phenolic content. Accumulation of phenolic compounds in response to an infection in plants was reported by Hammerbacher et al. (2011) who confirmed that phenolic compounds are produced through the phenylpropanoid pathway and/or rapid translocation and modification of existing compounds. The accumulation of phenolic compounds, in chili plants, at the site of the infection with anthracnose disease was correlated with the limitation of pathogen development, since these compounds are toxic to pathogens (Jayapala et al. 2019). Resistance may also be increased by changing the $\mathrm{pH}$ of plant cell cytoplasm due to an increase in phenolic acid

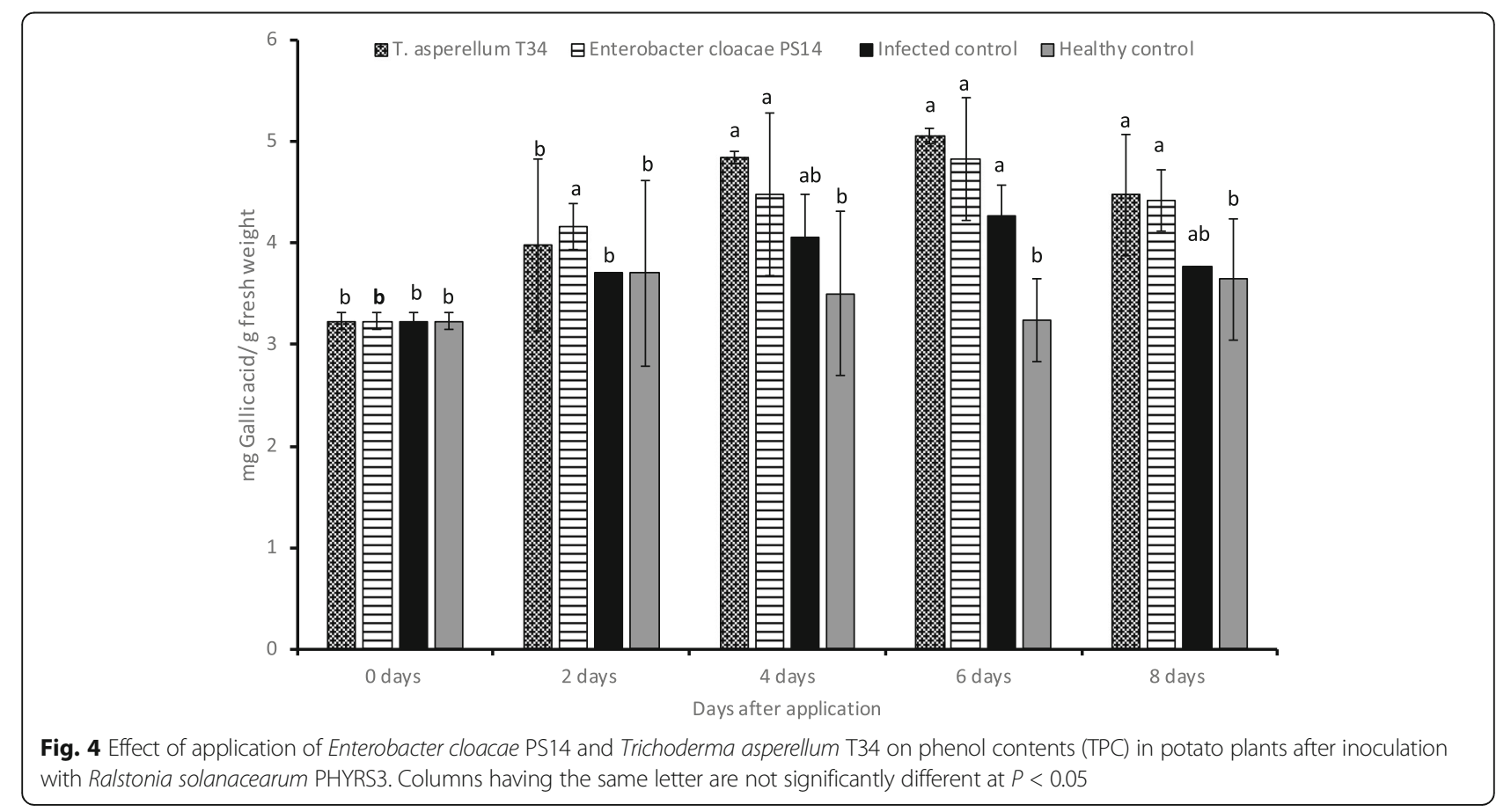


content that inhibits of development of pathogen (Bereika 2008; Hassan and Abo-Elyousr 2013).

\section{Enzymatic activities}

Peroxidase (PO) activity The results displayed that $T$. asperellum T34 significantly induced the maximum levels of $\mathrm{PO}$ activity in potato leaves infected with pathogen on the 8th day after inoculation than the either infected or heathy plants (Fig. 5). However, E. cloacae PS14 showed the highest level of PO activity in potato leaves on the 4th day after inoculation. This finding is supported by several reports that mentioned the enhanced PO activity in plants, when they were subjected to fungal, bacterial, and viral infections (Safdarpour and Khodakaramain 2018). Peroxidase caused lignin biosynthesis that provides a physical barrier and/or limits the degree of pathogen invasion and spread throughout the plant (Vidhyasekaran 2008). POX increases due to systemic resistance, a rapid synthesis of reactive oxygen derivatives by oxidative burst contributes to cell death and prevents pathogenic activity (Prasannath et al. 2014).

Polyphenol oxidase (PPO) activity Treatment of potato plants with $T$. asperellum $\mathrm{T} 34$ and E. cloacae PS14, after infection with the pathogen, induced the PPO activity in the potato plants in varied levels (Fig. 6). After 2 days from inoculation, potato plants treated with $T$. asperellum T34 exhibited a significant gradual increase in PPO activity until the 8th day than the only infected or healthy plants. E. cloacae PS14 showed a high level of PPO activity from the 2nd until the 4th day, and then PPO decreased on the 6th and 8th days than the only infected plants. The significance of PPO activity in disease resistance probably be due to its property of oxidizing phenolic compounds to quinines, it is often more toxic to microorganisms than the original phenol (Safdarpour and Khodakaramain 2018). Generally, toxicity of PPO-created quinones to pathogens and plant cells, inducing cell death, alkylation and decreased bioavailability of cell proteins to the pathogen, crosslinking protein or other phenolic quinones, forming a physical barrier to cell wall pathogens and quinone redox cycling leading to $\mathrm{H}_{2} \mathrm{O}_{2}$ and other reactive oxygen specificities (Konappa et al. 2018).

Lipoxygenase (LOX) activity T. asperellum T34 and E. cloacae PS14 significantly increased the activity of lipoxygenase (LOX) in potato leaves infected with the pathogen than either only infected or healthy plants (Fig. 7). Increase in LOX level began after 2 days from inoculation of plant with the bioagents till 8 days; however, T. asperellum T34 showed higher activity of LOX than E. cloacae PS14. The results agree with those of Kurabachew and Wydra (2013). This might be due to the fact that pathogen inoculation does not affect linoleate-consuming LOX. In potato plants, which could be due to an increase in the level of transcription of the two isoforms of LOX: Tomlox D and Tomlox E. LOX products contribute to the defense reaction in plants-pathogen interaction by inhibiting pathogen growth, phytoalexin accumulation, and signal transduction (Mariutto et al. 2011).

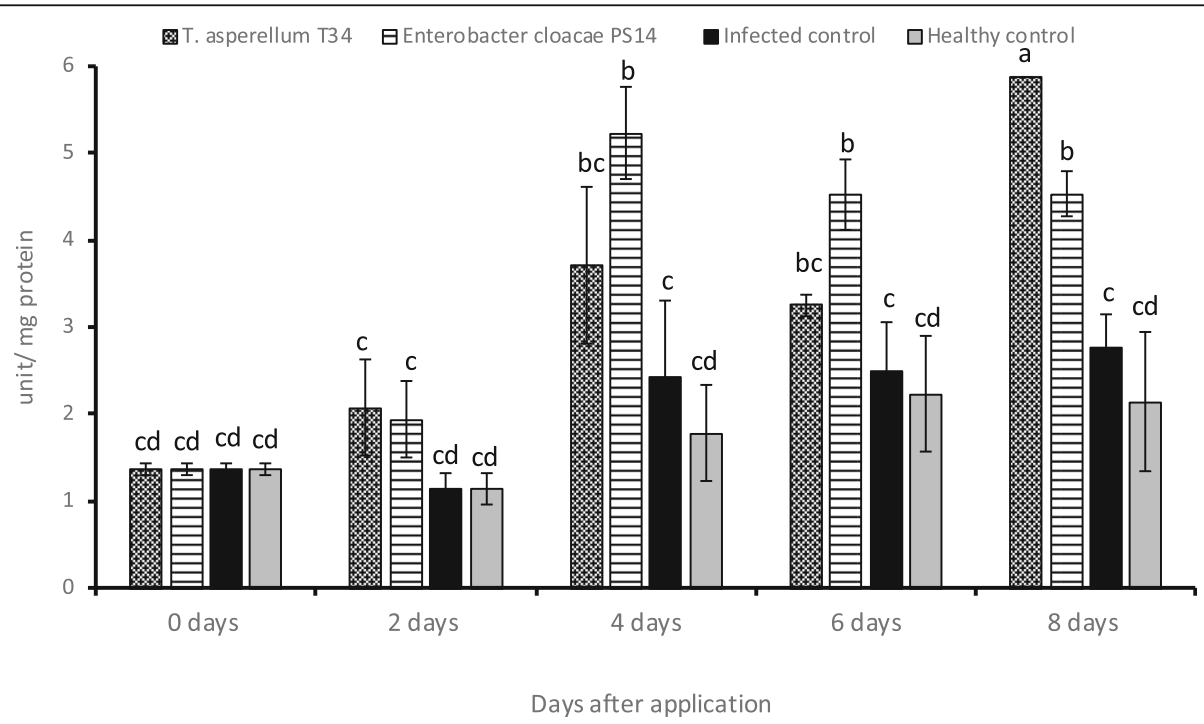

Fig. 5 Effect of application of Enterobacter cloacae PS14 and Trichoderma asperellum T34 on peroxidase activity (PO) in potato plants after inoculation with Ralstonia solanacearum PHYRS3. Columns having the same letter are not significantly different at $P<0.05$ 


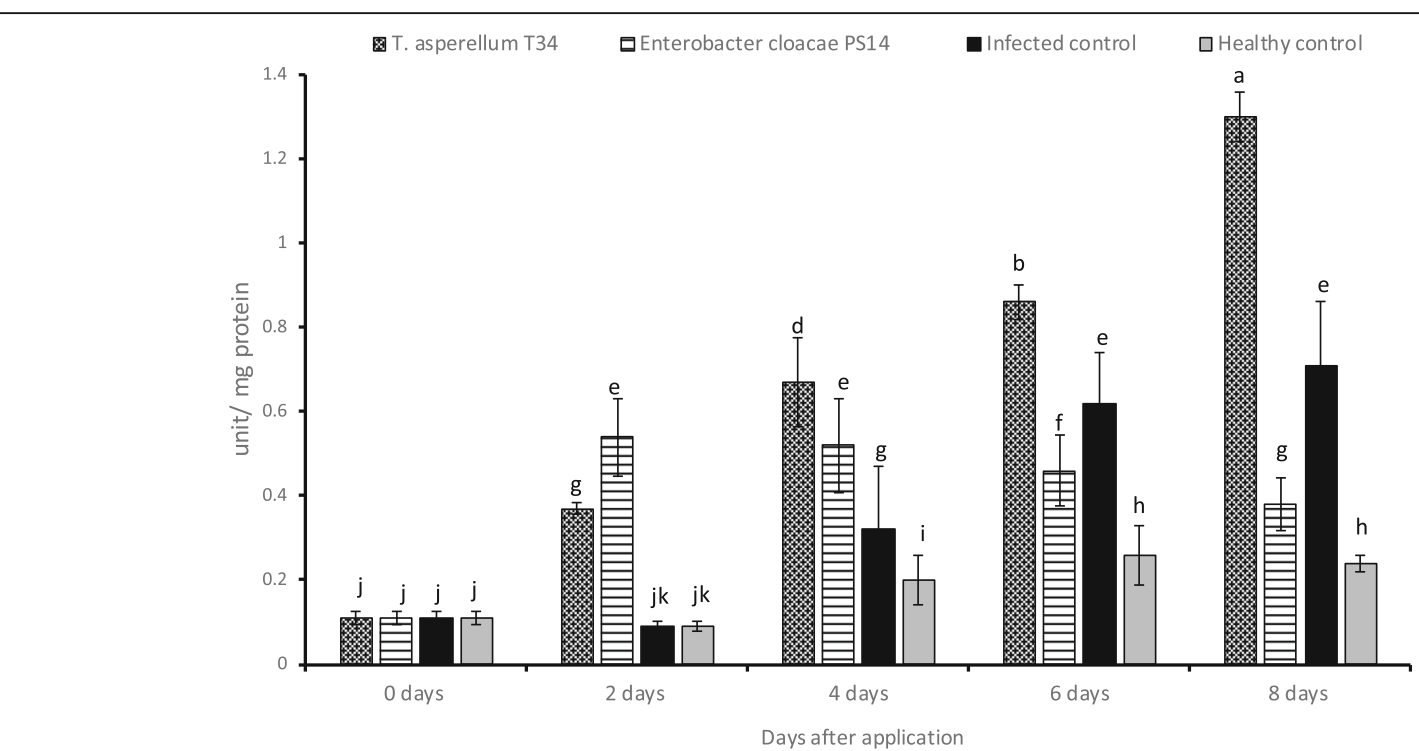

Fig. 6 Effect of application of Enterobacter cloacae PS14 and Trichoderma asperellum T34 on poly phenol oxidase activity (PPO) in potato plants after inoculation with Ralstonia solanacearum PHYRS3. Columns having the same letter are not significantly different at $P<0.05$

In vitro production of siderophore, HCN, IAA, and SA by E. cloacae PS14 and T. asperellum T34 to confirm their possible mode of action

Both microorganism, E. cloacae PS14 and T. asperellum T34, were able to produce a considerable amount of siderophore, HCN, IAA, and SA (Table 4). The endophytic bacterial E. cloacae PS14 produced a higher amount of siderophore, $\mathrm{HCN}$, and SA than T. asperellum T34; however, the situation was reversed in the case of IAA. E. cloacae PS14 produced $0.884,3.61$, and $1.488 \mu \mathrm{g} / \mathrm{ml}$ of siderophore, $\mathrm{HCN}$, and $\mathrm{SA}$, respectively. T. asperellum T34 produced $0.225 \mu \mathrm{g} / \mathrm{ml}$ of IAA. Our findings could be supported by those of Calin et al. (2019) who reported that $T$. asperellum had the ability to produce IAA. That is recognized as the key plant growthpromoting substance regulating plant physiological and developmental functions (Srisuk et al. 2018). Trichoderma spp. can produce IAA with varied amounts (Mohiddin et al. 2017). In other work, E. cloacae strain OSO3 had the ability to produce IAA in varying levels in

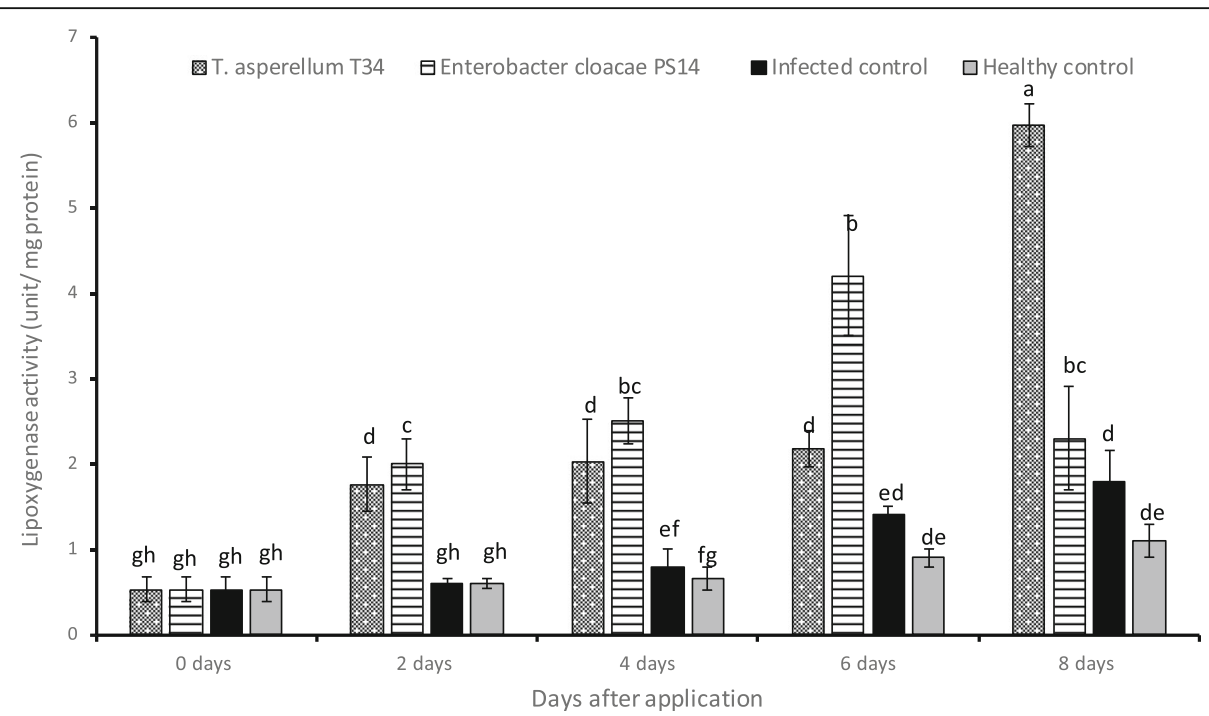

Fig. 7 Effect of application of Enterobacter cloacae PS14 and Trichoderma asperellum T34 on lipoxygenase activity (LOX) in potato plants after inoculation with Ralstonia solanacearum PHYRS3. Columns having the same letter are not significantly different at $P<0.05$ 
Table 4 Production of siderophore, HCN, IAA, and SA by Enterobacter cloacae PS14 and Trichoderma asperellum T34 in vitro

\begin{tabular}{lllll}
\hline Bioagents & Siderophore production $(\mu \mathrm{mol})$ & $\mathrm{HCN}$ production $\mu \mathrm{g} / \mathrm{ml}$ & $\mathrm{IAA}(\mu \mathrm{g} / \mathrm{ml})$ & $\mathrm{SA}(\mu \mathrm{g} / \mathrm{ml})$ \\
\hline Trichoderma asperellum T34 & 0.577 & 2.34 & 0.225 & 0.436 \\
Enterobacter cloacae PS14 & 0.884 & 3.61 & 0.133 & 1.488
\end{tabular}

the medium containing L-tryptophan than under a cop of physicochemical conditions (Panigrahia et al. 2019). Sheng et al. (2008) mentioned that E. cloacae could have a significant impact on the growth of plants, in particular by producing IAA (Panigrahia et al. 2019). Siderophores are iron chelating compounds that have a serious part in the field such as agriculture, bioremediation, biosensor, and medicine (Venkat et al. 2017). In a similar report to ours, E. cloacae strain PGLO9 exhibited activity of siderophore production and showed a positive antagonistic ability to phytopathogens (Verma et al. 2018). Trichoderma can produce siderophores to control plant disease and promote growth opportunities to replace chemical pesticides (Calin et al. 2019). Siddiqui et al. (2006) reported that $\mathrm{HCN}$ production is an important feature found in different microorganisms, since it indirectly promotes plant growth by controlling certain soilborne diseases (Siddiqui et al. 2006). Positive correlation has been documented between production of $\mathrm{HCN}$ in vitro and plant protection and their defense system. It was thought that $\mathrm{HCN}$ direct inhibition of fungi was one of the major mechanisms of action. There are numerous reports on biocontrol activity of $\mathrm{HCN}$ production in the rhizosphere in tobacco plants. Also, it can stimulate the root length and root hair germination (Ghosh et al. 2018). Also, specific strain of E. cloacae (K2 strain) was reported as a good HCN-producer (Pramanik et al. 2018). T. asperellum-cucumber interaction increased SA and peroxidase activity as an induction response in the plants. In addition, after inoculation of Trichoderma into the plants, a systemic resistance of plants increased as the increase in SA and JA rates were observed (Hermosa et al. 2012). Also, endophytic bacteria increased the growth of sunflower seedlings and inhibited the growth of pathogenic fungi by developing SA (Klessig et al. 2016).

\section{Conclusion}

The results conclude that the new endophytic strain of E. cloacae PS14 was a potent biocontrol agent against $R$. solanacearum-the causal pathogen of wilt of potato. The use of T. asperellum T34 and E. cloacae PS14 successfully suppressed the $R$. solanacearum in vitro, in vivo, and in situ. It caused reduction of the disease severity and increased the crop yield in a level close to $T$. asperellum T34. The main mechanism of action of the new bacterial strain was due to production of antibacterial agent as well as induction of systemic resistance of potato plant. Successful application of the new bacterial strain on the field scale for two successive seasons encourages its application on a large scale in biological control of plant disease, and further research to find an appropriate formulation and approving application of the new strain for a wide range of plant diseases was recommended.

\section{Abbreviations}

SA: Salicylic acid; LOX: Lipoxygenase; PPO: Polyphenol oxidase; PO: Peroxidase; IAA: Indole acetic acid production; HCN: Hydrogen cyanide

\section{Acknowledgements}

Not applicable

\section{Authors' contributions}

All authors contributed equally in the manuscript.

B.F.F.M. and N.M. S. suggested the idea of the work and contributed to data curation and their validation as well as writing the original draft. K.E. contributed to the formal analysis of the data. S.A., M.H., and Y.S.M. contributed to the reviewing and editing of the manuscript. All authors reviewed and approved the final version of the manuscript.

\section{Funding}

The research was funded by the Deanship of Scientific Research at King Khalid University through a research groups program under grant number R.G.P. 1/61/39.

\section{Availability of data and materials \\ Not applicable}

\section{Ethics approval and consent to participate}

This manuscript is in accordance with the guide for authors available on the journal's website. Also, this work has not been published previously and is approved by all authors and host authorities.

\section{Consent for publication}

All authors approve to publication.

\section{Competing interests}

No potential conflict of interest was reported by the authors.

\section{Author details \\ ${ }^{1}$ Ministry of Agriculture, Agriculture Administration, Sohag, Egypt. ${ }^{2}$ Plant Pathology Department, Faculty of Agriculture, Assiut University, Assiut, Egypt. ${ }^{3}$ Department of Biology, College of Science King Khalid University, Abha 61413, Saudi Arabia. ${ }^{4}$ Prince Sultan Ben Abdulaziz Center for Environmental and Tourism Research and Studies, King Khalid University, Abha, Saudi Arabia. ${ }^{5}$ Faculty of Meteorology, Env., and Arid Land Agriculture, Department of Arid Land Agriculture, King Abdulaziz University, Jeddah, Saudi Arabia. \\ ${ }^{6}$ Faculty of Science, Botany and Microbiology Department, Assiut University, Assiut, Egypt.}

Received: 26 February 2020 Accepted: 11 May 2020

Published online: 26 May 2020

\section{References}

Abd-Alla MH, Morsy FM, El-Enany AE, Ohyama T (2012) Isolation and characterization of a heavy-metal resistant isolate of Rhizobium leguminosrum bv viciae potentially applicable for biosorption of $\mathrm{Cd}^{2+}$ and $\mathrm{Co}^{2+}$. Int Biodeterior Biodegrad 67:48-55 
Abd-El-Khair H (2020) Biological Control of Phyto-pathogenic Bacteria. In: ElWakeil N, Saleh M, Abu-hashim M (eds) Cottage industry of biocontrol agents and their applications. Springer, Cham

Abo-Elyousr KAM, Bagy HMMK (2018) Control of tomato bacterial wilt using certain of plant ethanol extracts. J Phytopathol Pest Manag 5:77-84

Abo-Elyousr KAM, Hussein MAM, Allam A, Hassan M (2008) Enhanced onion resistance against stemphylium leaf blight disease, caused by Stemphylium vesicarium, by di-potassium phosphate and benzothiadiazole treatments. Plant Pathol J 24:171-177

Abo-Elyousr KAM, Ibrahim YE, Balabel NM (2012) Induction of disease defensive enzymes in response to treatment with acibenzolar-S-methyl(ASM) and Pseudomonas fluorescens Pf2 and inoculation with Ralstonia solanacearum race 3, biovar2 (phylotypell). J Phytopathol 160:382-389

Al-Mughrabi KI (2010) Biological control of Fusarium dry rot and other potato tuber diseases using Pseudomonas fluorescens and Enterobacter cloacae Biol. Control. 53:280-284

Axelred B, Cheesbrough TM, Laakso S (1981) Lipoxygenase from soybeans. Methods Enzymol 71:441-451

Batra GK, Kuhn CW (1975) Polyphenoloxidase and peroxidase activities associated with acquired resistance and it inhibition by 2 -thiouracil in virus infected soybean. Physiol Plant Pathol 5:239-248

Bereika MFF (2008) Studies on induction of resistance against potato brown rot caused by Ralstonia solanacearum. M.Sc. Thesis, Faculty of Agriculture, Assiut University, p 142

Bradford M (1976) A rapid and sensitive method for the quantitation of microgram quantities of protein utilizing the principle of protein dye binding. Anal Biochem 72:248-250

Calin M, Raut I, Arsene ML, Capra L, Gurban AM, Doni M, Jecu L (2019) Applications of fungal strains with keratin-degrading and plant growth promoting characteristics. Agron. 9:543

Chamedjeu RR, Joel M, Viviene M, Steven R (2019) Potential use of soil bacteria associated with potato rhizosphere as bio-control agents for effective management of bacterial wilt disease. J Microbiol Res 9:12-24

Dat JF, Foyer CH, Scott IM (1998) Changes in salicylic acid and antioxidants during induced thermotolerance in Mustard seedling. Plant Physiol 118 1455-1461

El-Sharkawya HHA, Rashadb YM, Ibrahimc AS (2018) Biocontrol of stem rust disease of wheat using arbuscular mycorrhizal fungi and Trichoderma spp. Physiol Mol Plant Pathol 103:84-91

Gaiero JR, McCall CA, Thompson KA, Day NJ, Best AS, Dunfield KE (2013) Inside the root microbiome: bacterial root endophytes and plant growth promotion. Am J Bot 100(9):1738-1750

Ghosh SK, Banerjee S, Pal S, Chakraborty N (2018) Encountering epidemic effects of leaf spot disease (Alternaria brassicae) on Aloe vera by fungal biocontrol agents in agri fields ĐAn ecofriendly approach. PLoS One 13(3):e0193720

Gomez KA, Gomez AA (1984) Statistical procedures for agricultural research. Wiley, New York

Götz M, Gomes NCM, Dratwinski A, Costa R, Berg G, Peixoto R, Mendonc L, Hagler H, Smalla K (2006) Survival of gfp-tagged antagonistic bacteria in the rhizosphere of tomato plants and their effects on the indigenous bacterial community FEMS Microbiol. Ecol. 56:207-218

Hammerbacher A, Ralph SG, Bohlmann J, Fenning TM, Gershenzon J, Schmidt A (2011) Biosynthesis of the major tetrahydroxystilbenes in spruce, astringin and isorhapontin, proceeds via resveratrol and is enhanced by fungal infection. Plant Physiol 157:876-890

Hassan MAE, Abo-Elyousr KAM (2013) Impact of compost application on Fusarium wilt disease incidence and microelements contents of basil plants. Arch Phytopathol Plant Protect 46:1904-1918

Hermosa R, Viterbo A, Chet I, Enrique M (2012) Plant-beneficial effects of Trichoderma and of its Genes. Microbiol. 158:17-25

Jayapala N, Mallikarjunaiah N, Puttaswamy H (2019) Rhizobacteria Bacillus spp. induce resistance against anthracnose disease in chili (Capsicum annuum L.) through activating host defense response. Egypt J Biol Pest Cont 29:45

Kempe J, Sequeira L (1983) Biological control of bacterial wilt of potatoes: attempts to induce resistance by treating tubers with bacteria. Plant Dis 67 499-503

Khan N, Bano A (2019) Exopolysaccharide producing rhizobacteria and their impact on growth and drought tolerance of wheat grown under rainfed conditions. PLoS One 14(9):e0222302

Klessig DF, Tian M, Choi HW (2016) Multiple targets of salicylic acid and its derivatives in plants and animals. Front Immunol 7:206
Konappa N, Krishnamurthy S, Siddaiah CN, Ramachandrappa NS, Chowdappa S (2018) Evaluation of biological efficacy of Trichoderma asperellum against tomato bacterial wilt caused by Ralstonia solanacearum Egypt. J Biol Pest Cont 28:63

Kurabachew H, Wydra K (2013) Characterization of plant growth promoting rhizobacteria and their potential as bioprotectant against tomato bacterial wilt caused by Ralstonia solanacearum Biol. Cont. 67:75-83

Ling N, Xue C, Huang Q, Yang X, Xu Y, Shen Q (2010) Development of a mode of application of bioorganic fertilizer for improving the biocontrol efficacy to Fusarium wilt. BioCont. 55:673-683

Mariutto M, Duby F, Adam A, Bureau C, Fauconnier ML, Ongena M, Thonart P, Dommes J (2011) The elicitation of a systemic resistance by Pseudomonas putida BTP1 in the tomato involves the stimulation of two lipoxygenase isoforms. BMC Plant Biol 11:1-15

Mercado-Blanco J, Lugtenberg BJJ (2014) Biotechnological applications of bacterial endophytes Curr. Biotechnol. 3:60-75

Meyer JM, Abdallah MA (1978) The fluorescent pigment of Pseudomonas fluorescens biosynthesis, purification and physiochemical properties. J Gen Microbiol 107:319-328

Mohiddin FA, Bashir I, Shahid AP, Burhan H (2017) Evaluation of different substrates for mass multiplication of Trichoderma species. J Pharm Phytochem 6:563-569

Nandhini S, Sendhilvel V, Babu S (2012) Endophytic bacteria from tomato and their efficacy against Fusarium oxysporum f.sp. lycopersici, the wilt pathogen. J Biopest 5:178-185

Panigrahia S, Mohantyb S, Rathc CC (2019) Characterization of endophytic bacteria Enterobacter cloacae MG00145 isolated from Ocimum sanctum with indole acetic acid (IAA) production and plant growth promoting capabilities against selected crops. South Afr J Botany https://doi.org/10.1016/j.sajb.2019.09.017

Peeters N, Guidot A, Fabienne V, Valls M (2013) Ralstonia solanacearum, a widespread bacterial plant pathogen in the post-genomic era. Mol Plant Pathol 14. https://doi.org/10.1111/mpp.12038

Podolich O, Ardanov P, Zaets I, Pirttilä AM, Kozyrovska N (2015) Reviving of the endophytic bacterial community as a putative mechanism of plant resistance. Plant Soil 388:367-377

Pramanik K, Soumik M, Anumita S, Tithi S, Tushar KM (2018) Characterization of a $\mathrm{Cd} 2 \mathrm{p}$-resistant plant growth promoting rhizobacterium (Enterobacter sp.) and its effects on rice seedling growth promotion under $\mathrm{Cd} 2 \mathrm{p}$-stress in vitro. Agric Nat Res 52:215-221

Prasannath K, Dharmadasa KNP, De Costa DM, Hemachandra KS (2014) Variations of incidence, types of virus diseases and insect vector populations of tomato (Solanum lycopersicum L.), grown in different agro- ecological regions of Sri Lanka under two crop management systems. Trop Agric Res 25:376-395

Putter J (1974) Peroxidase. In: Bergmeyer HU (ed) Methoden der enzymatischen Analyses. Verlag Chemie, Weinheim, p 725

Rapp A, Ziegler A (1973) Bestimmung der Phenolcarbonsaure in Rebblattern Weintraube und Wein mittels Polamyid-Dunnschicht Chromatographie. Vitis 12:226-236

Sadasivam S, Manickam A (1992) Biochemical methods for agricultural sciences. Wiley Eastern Ltd, New Delhi

Safdarpour F, Khodakaramain G (2018) Endophytic bacteria suppress bacterial wilt of tomato. Caused by Ralstonia solanacearum and Activate defense-related metabolites. Biol J Micro 6:39-52

Sallam NMA, Sallam A, Eraky A (2019) Effect of Trichoderma spp. on fusarium wilt disease of tomato. Mol Biol Rep 46:4463

Sanger F, Nicklen S, Coulson A (1977) DNA sequencing with chain- terminating inhibitors. Proc Natl Acad Sci U S A 74:5463-5467

Schwyn B, Neilands JB (1987) Universal chemical assay for the detection and determination of siderophores. Anal Biochem 196:47-56

Sheng XF, Xia JJ, Jiang CY, He LY, Qian M (2008) Characterization of heavy metalresistant endophytic bacteria from rape (Brassica napus) roots and their potential in promoting the growth and lead accumulation of rape. Environ Pollut 156:1164-1170

Siddiqui IA, Shaukat SS, Sheikh IH, Khan A (2006) Role of cyanide production by Pseudomonas fluorescens CHAO in the suppression of root-knot nematode, Meloidogyne javanica in tomato. World J Microbiol Biotechnol 22:641-650

Srisuk N, Sakpuntoon V, Nutaratat P (2018) Production of indole-3-acetic acid by Enterobacter sp. DMKU-RP206 using sweet whey as a low-cost feed stock. J Microbiol Biotechnol 28(9):1511-1516

Tsuda K, Kosaka Y, Tsuge S (2001) Evaluation of the endophyte enterobacter cloacae sm10 isolated from spinach roots for biological control against fusarium wilt of spinach. J Gen Plant Pathol 67:78-84 
Upreti R, Thomas P (2015) Root-associated bacterial endophytes from Ralstonia solanacearum resistant and susceptible tomato cultivars and their pathogen antagonistic effects. Front Microbiol 6:255

Venkat KS, Menon S, Agarwal H, Gopalakrishnan D (2017) Characterization and optimization of bacterium isolated from soil samples for the production of siderophores. Res Efficient Technol 3:434-439

Verma P, Agrawal N, Shahi SK (2018) Enterobacter cloacae strain PGLO9: potential source of maize growth promoting rhizobacteria. Inter J Bot Stud 3(2):172-175

Vidhyasekaran P (2008) Evasion and detoxification of secondary metabolites. In: Vidhyasekaran P (ed) Fungal pathogenesis in plants and crops: molecular biology and host defense mechanisms, 2nd edn. CRC Press, Boca Raton, pp 411-467

Vinayarani G, Prakash HS (2018) Growth promoting rhizospheric and endophytic bacteria from Curcuma longa $\mathrm{L}$. as biocontrol agents against rhizome rot and leaf blight diseases. Plant Pathol J 34(3):218-235

Winstead NN, Kelman A (1952) Inoculation techniques for evaluating resistance to Pseudomonas solanaccannii. Phytopathology 42:28-34

Woo SL, Ruocco M, Vinale F, Nigro M, Marra R, Lombardi N, Alberto P, Stefania L, Gelsomina M, Lorito M (2014) Trichoderma-based products and their widespread use in agriculture. Open Mycol J 8:71-126

Xue Q-Y, Chen Y, Li S, Chen L, Ding G, Guo GW, Guo JH (2009) Evaluation of the strains of Acinetobacter and Enterobacter as potential biocontrol agents against Ralstonia wilt of tomato. Biol Control 48:252-258

Yang H, Sun X, Song W (2000) Current development on induced resistance by plant growth promoting and endophytic bacteria. Acta Phytopathol Sin 30: $107-110$

Yuliar S, Kartadi F, Salmah A (2019) Combined use of Enterobacter cloacae MB20 and the microelements of copper and manganese to control damping-off of tomato. IOP Conf Ser: Earth Environ Sci 308:012025

\section{Publisher's Note}

Springer Nature remains neutral with regard to jurisdictional claims in published maps and institutional affiliations.

\section{Submit your manuscript to a SpringerOpen ${ }^{\circ}$ journal and benefit from:}

- Convenient online submission

- Rigorous peer review

- Open access: articles freely available online

- High visibility within the field

- Retaining the copyright to your article

Submit your next manuscript at $\boldsymbol{\nabla}$ springeropen.com 